\title{
Study on the Application of Biocides in the Seawater Cooling System and Their killing Effect in the Laboratory
}

\author{
Xuejun Xie ${ }^{1, *}$, Yuan-lin Zhang ${ }^{1}$, Yu Zhang ${ }^{1}$, Hao Fu ${ }^{2}$, Mao-cai Gong ${ }^{2}$, Lin Tian $^{3}$ \\ and Qiang $\mathrm{Fu}^{4}$ \\ ${ }^{1}$ School of Power and mechanical engineering, Wuhan University, Wuhan, China, 430072 \\ ${ }^{2}$ Guodian hanchuan power generation co., LTD, hanchuan, P.R.China, 431614 \\ ${ }^{3}$ Cnooc zhuhai gas power generation co., LTD, Zhuhai, P.R.China, 519050 \\ ${ }^{4}$ Guangdong Power Grid Electric Power Science \& Research Institute, Guangzhou, P.R.China, \\ 510080 \\ ${ }^{*}$ Corresponding author
} Keywords: Biocides, Sodium hypochlorite, Benzalkonium bromide, Seawater Cooling System,
Killing effect, Laboratory.

\begin{abstract}
The application of biocides in the seawater cooling system and their killing effect in the laboratory is studied in the paper. The research result shows that sodium hypochlorite and benzalkonium bromide have good killing effect, the killing effect of sodium hypochlorite with $4 \mathrm{mg} / \mathrm{L}$ and benzalkonium bromide with $1.25 \mathrm{mg} / \mathrm{L}$ added in the seawater for $2 \mathrm{~h}$ is good, and the application of combining sodium hypochlorite with quaternary ammonium salt can be used in the killing of the seawater cooling system.
\end{abstract}

\section{Introduction}

There are two main forms to utilize the seawater as water resource, namely seawater desalinization and direct seawater application. In the coastal areas and sea islands region, that seawater is used as the industrial cooling water of thermal power, nuclear power, petrochemical, chemical, metallurgical and other industries, not only can save the fresh water, make other use of the limited fresh water resource to the largest extent, alleviate the contradiction between the shortage of fresh water and the industrial development, but also is an important way to solve the shortage of water resource in our country industry area, and will produce remarkable economic benefit and social benefit. At present, a batch of power plants, nuclear power plants cooled with seawater have been set up in China's coastal areas. [1-4]

The main ingredients of seawater are $\mathrm{Na}+, \mathrm{Cl}-, \mathrm{Mg} 2+, \mathrm{Ca} 2+, \mathrm{K}+, \mathrm{HCO} 3-, \mathrm{SO} 42-, \mathrm{Br}-$, etc. The mass fraction of salt in the general seawater is of $3 \%$ to $3.5 \%$ (the salt content is 30000 to 35000 $\mathrm{mg} / \mathrm{L}$ ). Because the salt content of seawater is high, and there are many types of macroorganism and microorganism and their content is high in seawater, there are a strong tendency of corrosion, scaling, biological growth and adhesion to the seawater cooling system, and the salt fog spray problem, etc in the seawater cooling system. After the seawater circulating cooling technology is used, the salt content of the seawater increases, corrosion, scaling and microorganism breeding and other issues become more prominent.[1-4] Therefore, it is necessary to do good research of anti-scale, anti-corrosion and killing technology of the cooling water system, especially the seawater circulating cooling system. The application of biocides in the seawater cooling system and their killing effect in the laboratory are introduced in the paper.

\section{Biocide Which Can Be Used In The Cooling Water System [5-8]}

One of the most effective and common method to control microorganism growth in the cooling water system is to add killing agent into the cooling water. 
Biocide is also called germicide and algicide, microbicides or fungicide. The biocide used in the cooling water system is referred to as the cooling water biocide. According to the incomplete statistics, nearly 80 kinds of biocides, generally divided into oxidizing and non oxidizing biocide two categories, are used in the current domestic industrial circulating cooling water.

The oxidizing biocide used commonly includes chlorine, hypochlorite such as sodium hypochlorite and calcium hypochlorite etc, chlorinated isocyanuric acid such as trichloride isocyanuric acid (trichloroisocyanuric acid) and sodium dichloroisocyanurate etc, chlorine dioxide, ozone, bromine and bromide.

The non oxidizing biocide used commonly includes chlorine phenol such as double chlorophenol, trichlorophenol and pentachlorophenol, organotin compounds such as tributyltin chloride, hydroxide tributyltin and tributyltin oxide, etc, quaternary ammonium salt such as benzalkonium chloride (geramine), dodecyl dimethyl benzyl ammonium bromide ( new geramine), etc, organic amine such as rosin amine, etc, organic sulfur compounds such as methylene sulfur cyano, etc, copper salts such as copper sulfate, isothiazolinone, bromide propionamide such as 2,2-Dibromo-3-nitrilopropionamide (DBNPA), glutaraldehyde and quaternary phosphorus salt.

\section{Biocide Which Can Be Used In The Seawater Cooling System [9-13]}

Due to the biological's environment adaptability, namely biological's genetic material changes with the change of environment, biological's resistant becomes inevitable if a biocide is used for a long time. According to some power plants' operating experience, performance evaluation and field application effect, the killing effect of a single kind of biocide is not good, and the mass concentration of the used biocide increases and its cost rises. So, to combine the traditional biocide chlorine with the non oxidizing biocide is necessary.

From the investigated market situation, there are many kinds of biocides, most of them are used in the freshwater cooling system, and fewer is aiming at the complex seawater circulating cooling system. Because there are many types of marine organisms in seawater, the higher requirement for the biocide performance is put forward. With the improvement of environmental protection consciousness, the traditional efficient biocide is gradually restricted to be used. In order to balance the environmental protection, economic benefits and the killing effect, the killing method to combine the traditional biocide chlorine with the non oxidizing biocide, such as to combine sodium hypochlorite with quaternary ammonium salt, is chosen.

\section{Sodium Hypochlorite}

After many years of practice, chlorination treatment is considered to be more effective, and can prevent the marine organisms from adhesion and growth in the cooling water system. Chlorination can be realized through three ways, namely to add directly chlorine, to add sodium hypochlorite solution and sodium hypochlorite from seawater electrolysis. The first two is added into the cooling water system by dosing equipment. The latter is active chlorine $(\mathrm{HClO}, \mathrm{ClO}-, \mathrm{Cl} 2)$ produced by a special electrode to electrolyze sodium chloride $(\mathrm{NaCl})$ solution or the seawater, and it is added into the cooling water system to ensure the cooling water system, especially the heat exchanger's safe and economic operation. That the oxidizing biocide chlorine is used and the residual chlorine content is maintained to be greater than $0.1 \mathrm{mg} / \mathrm{L}$, and the non oxidizing biocide is used auxiliarily twice a month can effectively inhibit the growth of bacteria, algae and the soft marine organisms.

It is appropriate that chlorine is used as biocide when the $\mathrm{pH}$ of the cooling water is within the scope of 6.5 7.0. The killing ability of chlorine decreases when the $\mathrm{pH}$ is high. Usually, the $\mathrm{pH}$ of the cooling water is mostly 7.5 8.5, and the killing effect of chlorine is poor. Hypochlorite under acid condition is not stable and decompose rapidly. Slight overstability hypochlorite is produced in the presence of caustic soda in the electrolytic cell. The decomposition of hypochlorite occurs when it is in contact with bacteria, and its killing effect is more effective and more durable, especially it is applicable to the cooling water staying longer in the pipe. Furthermore, as a biocide, the dosage of sodium hypochlorite is less than that of chlorine. Since the middle and late 1990s, the technology of 
electrolyzing seawater to prepare sodium hypochlorite has gradually been digested and mastered in our country. At present the localization rate of the equipments is high, and the performance of the equipments is stable.

In the coastal power plants in China, adding the industrial sodium hypochlorite and the sodium hypochlorite produced by electrolyzing seawater are usually used as the methods of sterilizing and killing algae. Sodium hypochlorite is a strong oxidizer, which can destroy cell wall, affect the nutrient to be absorpted, and make the cell die.

Usually the industrial sodium hypochlorite with concentration of $10 \%$ is regularly added to the condenser cooling water system to sterilize and kill algae. This method is not suitable for the power plants which don't meet the requirement of electrolyzing seawater to produce chlorine, such as coastal power plants whose condenser cooling water is fresh water or seawater with low salt content, and where aquatic organisms such as shellfish grow less and the continuous dosing isn't needed. If the growth situation of the marine organisms is different, the difference of the dosing method and the dosing amount is great. The best advantage of adding sodium hypochlorite is that the one-time investment is less, its defect is that the transportation workload is heavy, intermittent dosing with large dose may lead to discharge excessive residual chlorine and cause environmental pollution.

Sodium hypochlorite produced by electrolyzing seawater is a strong oxidizer and light yellow transparent liquid with the appearance, and has the exciting taste similar to chlorine gas. Through oxidizing the enzymes in the body, it kills microorganisms, make the breathing system of the fouling organisms produce chemical damage, or make the attachment organs (chassis and filopod, etc) of fouling organisms shrink. As long as a certain concentration of chlorine is added on the protected objects (in the living environment of the attached biology), the life of the attached biology will be threatened and the goal of preventing its adhesion will be achieved. Usually it is added in the front pool for taking water for cooling and the goal of killing or expelling away the marine organisms and cleaning the system may be achieved.

By contrast with adding the industrial sodium hypochlorite, the advantages of adding the sodium hypochlorite produced by electrolyzing seawater includes large anti-fouling range ( because it is a broad-spectrum biocide, can kill or expel away all kinds of marine organisms, and the whole condenser seawater cooling system can be anti-fouling safely ), no pollution to the environment (because the continuous dosing method is adopted and small amount can maintain to be added, and the marine organisms don't be adhered. its harm to human body and the environment is weak at low concentration, and its active ingredient is easy to be biodegradation, absorption and chemical reaction, and the residual chlorine concentration decreases to 0 fast after dosing is stopped ), convenient daily management (because the technology has been very mature and the system operation is fully automatic), safe and reliable (the whole process completes in a closed system, and all the operation can complete in the control room, hydrogen produced in the process of electrolysis is discharge into the atmosphere through its storage tanks and there aren't any danger). So, no matter from the advancement of the technology, the safety of the system operation, or from the cost and the environmental protection effect, it is superior that adding sodium hypochlorite produced by electrolyzing seawater than adding liquid chlorine and the industrial sodium hypochlorite.

The working environment conditions of electrolyzing seawater to produce sodium hypochlorite include environment temperature, environment humidity, chloridion concentration, chemical oxygen demand, manganese ion concentration, water temperature, etc. The output of electrolyzing seawater to produce sodium hypochlorite depends mainly on the circulating water flow, dosing method and addition dosage, and addition dosage also depends on the types and characteristics of life of marine organisms. The usual marine organisms in seawater are mussels, oysters, barnacles, ascideans, calcarinas, algae and glue liquid.

The amount of chlorine consumed in all kinds of reaction is unable to be estimated. Even if the water source is same, the usage varies with water temperature, chlorine dosage and contact time, etc. Addition dosage can be determined by test. Practice proves that continuous dosing and addition dosage of about $1 \mathrm{mg} / \mathrm{L}$ to control the available chlorine content in the outlet water of the circulating water system to be $0.05 \mathrm{mg} / \mathrm{L}$ can effectively control growth of various marine organisms. 
For example, datang lvsi port power plant phase I project includes $4 \times 660 \mathrm{MW}$ thermal power units, has eight circulating water pumps whose total output is $8 \times 35000 \mathrm{~m} 3 / \mathrm{h}$. Water is taken from the sea area with distance $2.4 \mathrm{~km}$ away from the shore of the factory, and go through the cooling water pipes, the condenser and the drainage pipes, then flow into the yellow sea. Electrolyzing seawater is designed to produce chlorine to sterilize and kill algae for the cooling water treatment, prevent and control shellfish for the condenser, whose production capacity is $4 \times 480 \mathrm{~kg} / \mathrm{h}$ sodium hypochlorite.

2.2 Quaternary ammonium salt

There are many kinds of non oxidizing biocides, in which quaternary ammonium salt is ionic compound and easily soluble in the water, has stable chemical properties and good killing effect to shellfish and algae.

Quaternary ammonium salt is a kind of organic ammonium salt, low toxicity and high efficiency. Since alkyl dimethyl ammonium chloride's bactericidal effect has been found, four generations of quaternary ammonium salt biocide has been synthesized. Due to bacterial surface usually negatively charged, the cationic quaternary ammonium salt is the most and earliest used.

Alkyl dimethyl benzyl ammonium chloride (bromide) is the most widely used, its killing effect has a lot to do with the length of alkyl. It has universal and high efficient performance, and have stripping effect to the bacteria and algae sludge. The chemical bond formed through electrostatic interactions between cation of quaternary ammonium salt and the negative charge on the cell wall of fungi, and a pressure on the cell wall formed, will make the cell wall distort, distroy the tissue of cell semipermeable membrane, and cause dissolution and death of cell. Early quaternary ammonium salt is represented by dodecyl dimethyl benzyl ammonium chloride (1227), and geramine and new geramine used widely in domestic at present belong to this kind of product. With the progress of technology, the deficiency of this kind of quaternary ammonium salt is also gradually revealed, the main expressions are that its drug function duration is short, bacteria are easy to have resistant, and foam is more and difficult to be removed. In order to overcome the above shortcomings, abroad the new and representative quaternary ammonium salt has been developed, such as double alkyl quaternary ammonium salt,double quaternary ammonium salt, polymer quaternary ammonium salt, etc. At present this kind of product in domestic has certain production and application.

Quaternary ammonium salt is the most widely used biocide in China. Compared with oxidizing biocide such as chlorine, etc, it has the following advantages in environment, performance, cost, etc.

(1)Sulfate-reducing bacteria growing under the sludge can be killed, the killing effect to shellfish and algae is better, and the killing effect is nearly $100 \%$ to shellfish such as green shellfish, barnacles (oysters), which adhere strongly in the circulating water system and has large harm. Larger organisms such as barnacles, mussels, organisms are stimulated by high concentration of biocide through the role of the membrane formed on the metal and other materials surface, move, and are drived away by seawater, then pipe surface becomes smooth and organisms are hard to adhere on the pipe surface.

(2) The pollution to the environment is little. Quaternary ammonium salt is cationic biocide and easily absorbed by neutral or anionic material, then its toxicity degrades. So, it is no hazards to the water environment and beneficial microbes, no long-term impact on water quality, and no big damage to the floating creatures within a certain dose of biocide.

(3) One-time investment is less, and only two drug storage tanks and two set metering pumps are needed.

There are following disadvantages of quaternary ammonium salt used as biocide.

(1) It isn't a broad-spectrum biocide, its killing effect to the soft marine organisms such as water trematode is not ideal, and the ideal killing effect can achieve when oxidizing biocide such as chlorine or sodium hypochlorite, etc is added auxiliarily.

(2) Foam produced is more when used, false water level is easy to form, and defoaming agent is needed.

Quaternary ammonium salt biocide is commonly added intermittently. Frequency, dosing time and dosage of intermittent dosing depend on growth conditions of marine organisms in the circulating water. Addition dosage usually depends on seawater temperature, water quality and the types of 
marine organisms. The usual adding way recommended is that once with the concentration $3 \sim 8 \mathrm{mg} / \mathrm{L}$ quaternary ammonium salt for $5 \sim 24 \mathrm{~h}$ every $5 \sim 30 \mathrm{~d}$, such as once with the concentration $5 \mathrm{mg} / \mathrm{L}$ for $10 \mathrm{~h}$ every two weeks in the slack season of marine organisms growth, and once with the concentration $6 \mathrm{mg} / \mathrm{L}$ for $10 \mathrm{~h}$ every one week in the busy season of marine organisms growth.

The test seawater is from Zhuhai cross drain, provided by Guangdong Power Grid Electric Power Science \& Research Institute. The conventional water quality analysis result of the seawater is shown in table 1 .

Table 1. The conventional water quality analysis result of the seawater

\begin{tabular}{|c|c|c|c|c|c|c|c|}
\hline No. & Analysis item & Unit & Result & No. & Analysis item & Unit & Result \\
\hline 1 & Total solid & $\mathrm{mg} / \mathrm{L}$ & 23210.00 & 17 & $\mathrm{Mg}^{2+}$ & $\mathrm{mg} / \mathrm{L}$ & 750.39 \\
\hline 2 & Dissolved solid & $\mathrm{mg} / \mathrm{L}$ & 22400.00 & 18 & $\mathrm{NH}_{4}^{+}$ & $\mathrm{mg} / \mathrm{L}$ & $<0.10$ \\
\hline 3 & Suspended solid & $\mathrm{mg} / \mathrm{L}$ & 810.00 & 19 & $\mathrm{~F}^{-}$ & $\mathrm{mg} / \mathrm{L}$ & $<0.10$ \\
\hline 4 & Total hardness & $\mathrm{mmol} / \mathrm{L}$ & 40.60 & 20 & $\mathrm{Cl}^{-}$ & $\mathrm{mg} / \mathrm{L}$ & 11525.82 \\
\hline 5 & $\begin{array}{l}\text { Carbonate } \\
\text { hardness }\end{array}$ & $\mathrm{mmol} / \mathrm{L}$ & 2.20 & 21 & $\mathrm{NO}_{2}^{-}$ & $\mathrm{mg} / \mathrm{L}$ & $<0.10$ \\
\hline 6 & $\begin{array}{c}\text { Non-carbonate } \\
\text { hardness }\end{array}$ & $\mathrm{mmol} / \mathrm{L}$ & 38.40 & 22 & $\mathrm{NO}_{3}^{-}$ & $\mathrm{mg} / \mathrm{L}$ & 6.10 \\
\hline 7 & Total alkalinity & $\mathrm{mmol} / \mathrm{L}$ & 2.20 & 23 & $\mathrm{SO}_{4}^{2-}$ & $\mathrm{mg} / \mathrm{L}$ & 1694.38 \\
\hline 8 & $\begin{array}{c}\text { Phenolphthalein } \\
\text { alkalinity }\end{array}$ & $\mathrm{mmol} / \mathrm{L}$ & 0.00 & 24 & $\mathrm{PO}_{4}{ }^{3-}$ & $\mathrm{mg} / \mathrm{L}$ & $<0.10$ \\
\hline 9 & $\begin{array}{c}\text { Free carbon } \\
\text { dioxide }\end{array}$ & $\mathrm{mg} / \mathrm{L}$ & 12.76 & 25 & $\mathrm{HCO}_{3}^{-}$ & $\mathrm{mg} / \mathrm{L}$ & 134.38 \\
\hline 10 & All silicon & $\mathrm{mg} / \mathrm{L}$ & 2.55 & 26 & $\mathrm{CO}_{3}{ }^{2-}$ & $\mathrm{mg} / \mathrm{L}$ & 0.00 \\
\hline 11 & Activated silica & $\mathrm{mg} / \mathrm{L}$ & 2.49 & 27 & $\mathrm{OH}^{-}$ & $\mathrm{mg} / \mathrm{L}$ & 0.00 \\
\hline 12 & $\begin{array}{l}\text { Non-activated } \\
\text { silica }\end{array}$ & $\mathrm{mg} / \mathrm{L}$ & 0.06 & 28 & $\mathrm{pH}\left(25^{\circ} \mathrm{C}\right)$ & I & 7.44 \\
\hline 13 & $\begin{array}{c}\text { Chemical } \\
\text { oxygen demand } \\
(\text { CODMn })\end{array}$ & $\mathrm{mg} / \mathrm{L}$ & 11.78 & 29 & Total iron & $\mathrm{mg} / \mathrm{L}$ & 0.12 \\
\hline 14 & $\mathrm{~K}^{+}$ & $\mathrm{mg} / \mathrm{L}$ & 203.57 & 30 & Turbidity & NTU & 1.56 \\
\hline 15 & $\mathrm{Na}^{+}$ & $\mathrm{mg} / \mathrm{L}$ & 6882.43 & 31 & $\begin{array}{c}\text { Electrical } \\
\text { conductivity }\end{array}$ & $\mathrm{ms} / \mathrm{cm}$ & 32.40 \\
\hline 16 & $\mathrm{Ca}^{2+}$ & $\mathrm{mg} / \mathrm{L}$ & 218.07 & & & & \\
\hline
\end{tabular}

\section{The Killing Effect of Sodium Hypochlorite and Benzalkonium Bromide}

\section{The Test Method for Killing}

Take 5 reagent bottles of $1000 \mathrm{~mL}, 800 \mathrm{~mL}$ seawater sample and sodium hypochlorite or benzalkonium bromide with different dosage are added in each bottle, and bottles are placed in the water of the constant temperature water-bath at $45^{\circ} \mathrm{C}$. After biocide is added in the seawater, sampling analysis of residual chlorine and bacteria is immediately done, and it is done again after $2 \mathrm{~h}$. After 24h, sampling analysis of residual chlorine and bacteria should be done and a certain amount of biocide is added in each bottle to make the biocide concentration double, then sampling analysis of residual chlorine and bacteria is done. After $48 \mathrm{~h}$, sampling analysis of residual chlorine and bacteria should be done. 


\section{The Killing Effect of Sodium Hypochlorite and Benzalkonium Bromide}

The killing effect of sodium hypochlorite or benzalkonium bromide with different dosage is shown in table 2 , and the killing effect of sodium hypochlorite with $8 \mathrm{mg} / \mathrm{L}$ or benzalkonium bromide with $5 \mathrm{mg} / \mathrm{L}$ is shown in table 3.

Table 2. The killing effect of sodium hypochlorite or benzalkonium bromide with different dosage

\begin{tabular}{|c|c|c|c|c|}
\hline Biocide & $\begin{array}{c}\text { Concentration } \\
(\mathrm{mg} / \mathrm{L})\end{array}$ & Time (h) & $\begin{array}{c}\text { Residual } \\
\text { chlorine }(\mathrm{mg} / \mathrm{L})\end{array}$ & $\begin{array}{c}\text { Bacterium } \\
\text { number } / \mathrm{mL}\end{array}$ \\
\hline Seawater (blank) & / & I & 1 & $1.8 \times 10^{6}$ \\
\hline \multirow{10}{*}{$\mathrm{NaClO}$} & \multirow{5}{*}{4} & 0 & 0.8342 & $1.8 \times 10^{6}$ \\
\hline & & 2 & 1 & $3 \times 10^{5}$ \\
\hline & & 24 & 0 & 1 \\
\hline & & $\begin{array}{c}\text { 24(biocide is added } \\
\text { again) }\end{array}$ & 0.8342 & $10 \times 10^{5}$ \\
\hline & & 48 & 0 & 1 \\
\hline & \multirow{5}{*}{8} & 0 & 2.5025 & $18 \times 10^{5}$ \\
\hline & & 2 & 1 & $2 \times 10^{5}$ \\
\hline & & 24 & 0 & I \\
\hline & & $\begin{array}{c}\text { 24(biocide is added } \\
\text { again) }\end{array}$ & 3.7537 & $8 \times 10^{5}$ \\
\hline & & 48 & 0 & I \\
\hline \multirow{10}{*}{$\begin{array}{l}\text { Benzalkonium } \\
\text { bromide }\end{array}$} & \multirow{5}{*}{1.25} & 0 & 1 & $18 \times 10^{5}$ \\
\hline & & 2 & 1 & $4 \times 10^{5}$ \\
\hline & & 24 & I & 1 \\
\hline & & $\begin{array}{c}\text { 24(biocide is added } \\
\text { again) }\end{array}$ & I & $4 \times 10^{5}$ \\
\hline & & 48 & 1 & 1 \\
\hline & \multirow{5}{*}{2.5} & 0 & 1 & $1.8 \times 10^{6}$ \\
\hline & & 2 & I & $2 \times 10^{5}$ \\
\hline & & 24 & 1 & 1 \\
\hline & & $\begin{array}{c}\text { 24(biocide is added } \\
\text { again) }\end{array}$ & / & $2 \times 10^{5}$ \\
\hline & & 48 & 1 & 1 \\
\hline
\end{tabular}

Table 3. The killing effect of sodium hypochlorite with $8 \mathrm{mg} / \mathrm{L}$ or benzalkonium bromide with $5 \mathrm{mg} / \mathrm{L}$ added in the seawater for $2 \mathrm{~h}$

\begin{tabular}{|c|c|c|}
\hline Water sample & \multicolumn{2}{|c|}{ Bacterium number $/ \mathrm{mL}$} \\
\hline Seawater (blank) & $1.5 \times 10^{6}$ & $1.7 \times 10^{6}$ \\
\hline Seawater $+\mathrm{NaClO}(8 \mathrm{mg} / \mathrm{L})$ & $4 \times 10^{5}$ & $4 \times 10^{5}$ \\
\hline Seawater + benzalkonium bromide $(5 \mathrm{mg} / \mathrm{L})$ & $2 \times 10^{5}$ & $2 \times 10^{5}$ \\
\hline
\end{tabular}

As shown in table 2 and table 3 , the killing effect of sodium hypochlorite with $4 \mathrm{mg} / \mathrm{L}$ or $8 \mathrm{mg} / \mathrm{L}$ or benzalkonium bromide with $1.25 \mathrm{mg} / \mathrm{L}$ or $2.5 \mathrm{mg} / \mathrm{L}$ or $5 \mathrm{mg} / \mathrm{L}$ added in the seawater for $2 \mathrm{~h}$ is good.

\section{Conclusions}

Sodium hypochlorite and benzalkonium bromide have good killing effect. The killing effect of sodium hypochlorite with $4 \mathrm{mg} / \mathrm{L}$ or benzalkonium bromide with $1.25 \mathrm{mg} / \mathrm{L}$ added in the seawater for 
$2 \mathrm{~h}$ is good. The application of combining sodium hypochlorite with quaternary ammonium salt can be used in the killing of the seawater cooling system.

\section{References}

[1] Bao Yanjun. Study on manner of dosing for circulating cooling water system in Zhuhai Power Station. Guangdong Electric Power.2006 Vol.19 No.10: 22-25.

[2] Chen Haiyan, Lin Zhenlong, Chen Pimao, Qin Chuanxin, Tang Zhenzhao, Yu Jing. Electrochemical corrosion behavior of copper in marine microbial medium. Journal of materials engineering. No. 7(2014):22-27.

[3] Ji Xiaohui, Lin Jianzhong. The Study on The Treatment Method of Circulating Cooling Water System of The Sea Water Cooling Tower. Guangdong Chemical Industry.2010 Vol.37 No.5: 184-186, 190.

[4] Zhang Yuzhong, Peng Xiaomin. Treatment technology of seawater as circuating cooling water. Industrial water treatment. 2004 Vol.24 No.8: 14-17.

[5] Wang Guangzhu, Li Chengrong, Zhou Jinde, Luo Jianghe, Wang Deliang, Fan Kun, Ding Jianhe, Ren Qingjie, Chen Baoqi, Huang Xiaozhong. Study on sea water circulatory cooling technology and present state of its application. Thermal Power generation. 2007(11): 68-71.

[6] Chen Jun, Wang Jianzhang, Yan Fenyuan, Zhang Qing, Li Quanan. Corrosion wear synergistic behavior of Hastelloy C276 alloy in artificial seawater. Trans. Nonferrous Met. Soc. China 25(2015): 661-668.

[7] Hou Chunyang, Wu Jie, Zhao Nan, Wu Yunfang, Liu Shujing, Wang Weizhen. Corrosion control, fouling deposit control and biofouling control in the seawater circulating cooling system. Ocean technology. 2002 Vol.21 No.4: 46-50.

[8] Niu Yan, Lin Zhen long, Lin Guoji, Fang Yanxiong, Chen Haiyan, Chen Pimao, Yu Jing. Research on corrosion behavior of Q235 steel in marine iron- oxidizing bacteria. Marine environmental science. Vol.33, No. 5(2014):739-744.

[9] Liu Jin, Liu Zheng, Xie Siwei, Liu Baoyu. Study on corrosion performance of carbon steel in seawater with corrosion inhibitor of compounding schiff base. Marine Sciences.Vol.38, No. 5(2014): 16-23.

[10] Fan Xiaomei. How to deal with cooling water in littoral power plants. Journal of Chongqing Electric Power College.2006 Vol.11 No.4: 22-24.

[11] Cai Guowei, Yang Lihui, Li Yantao, Chu Tonglin. Research and development of corrosion Inhibitiors for carbon steel in Seawater. Corrosion \& Protection. Vol. 36, No. 2(2015): 101-107.

[12] Tang Dongsheng. Selection of Treatment Options for Sea Water Circulating Cooling Water. Electric Power Construction.2003 Vol.24 No.5: 12-14.

[13] Guo Zhaogeng. The water treatment method optimization of the circulating cooling system used Yellow sea seawater as cooling water. Silicon Valley.2012 No.20: 118-119. 